\title{
REGIONAL PECULIARITIES OF MANAGEMENT AND MOTIVATION OF PERSONNEL ON THE EXAMPLE OF MAGADAN CITY
}

\author{
Shklyar Tatiana Lvovna \\ candidate of economic sciences, associate Professor of Advertising, public relations and design, \\ Plekhanov Russian University of Economics \\ E-mail:tlb@mail.ru
}

\begin{abstract}
The earth's population keeps growing. Denser cities are filled with inhabitants. However, in the study of the Magadan region is possible to observe the opposite picture. The outflow of the population due to harsh climate and remoteness of the region from the Central regions of Russia to impose certain restrictions on the use of standard methods of management and motivation. There is a need to analyze the application of the standard Toolkit, its deformation under the needs of the region, which is described in this article. The author aims to consider the peculiarities of application of methods of personnel administration in Magadan. Special attention was paid to the motivations, values and priorities among employees, formed in the region. The article introduces concepts such as the syndrome of delayed life, the altruistic deformation of the personality, a conflict of obligation, internal reference, etc., and analyzes their impact on management. The author has used the results of the research obtained through: personal interview; projective techniques such as metaphorical maps, test Machover K. "the human figure", psihosomaticheskoy test Dallinger S., the Association with color, as well as, the definition of value orientations on Rakitu M. Considered three areas of management practices: economic, socio-psychological and administrative law. In each direction allocated to the main tools, and proposes a use with the features of the region. As a result, it was proposed to introduce a system of rating employees, which allows to neutralize the distinctive psychological traits of personnel. The obtained results can be used by executives in the Magadan region in the private and public sector.
\end{abstract}

Keywords: regional peculiarities, management, Magadan city

\section{INTRODUCTION}

Magadan is a port city in the Far East of Russia. It is the administrative center of Magadan region, the most remote from the capital of Russia1. Magadan region is one of the regions of Russia with the least population, along with Yakutia, the Nenets and Chukotka autonomous regions; the population density is only 0.3 people per square $\mathrm{km}$. The Kolyma route from Magadan to Yakutsk and the Magadan port play a fundamental role in providing life support in this region.

This city is characterized by extremely severe natural and climatic conditions, a zone of negative average annual temperatures. Winter in its severity has no equal in Eurasia.

Magadan was founded in 1929 and on July 14, 1939 received the status of a city. Initially, it was created as a base for supplying gold mines. For the most part, Kolyma used forced labor of prisoners. In 1932, Magadan became the center of the North-East Correctional Labor Camp; in the

1 Wikipedia. Population of Magadan region [Electronic resource]URL: https:// ru.wikipedia.org/ (accessed date 29.06.2017) 
late 1930s it became famous as the most cruel place of imprisonment, since many could not survive the winter on the Kolyma. The maximum influx of people occurred during the years of mass repression (1937-1939), in 1940 the number of prisoners exceeded 190 thousand people 2 . After the Second World War, former Soviet prisoners of war were added.

The present borders of Magadan region were established in late 1953, after the death of Stalin. During the Soviet era, it included the Chukotka Autonomous region that later became an independent entity in 1992.

Since the mid-1950's many migrants went to Magadan region for high wages provided by the state, as a result of which active industrial development began. In the period of 1959-1989, the population of the region has doubled, and Magadan became one of the big cities with its population exceeding 150 thousand people. In the post-Soviet period, the state sharply reduced financial support, many enterprises turned out unprofitable (see Fig. 1).

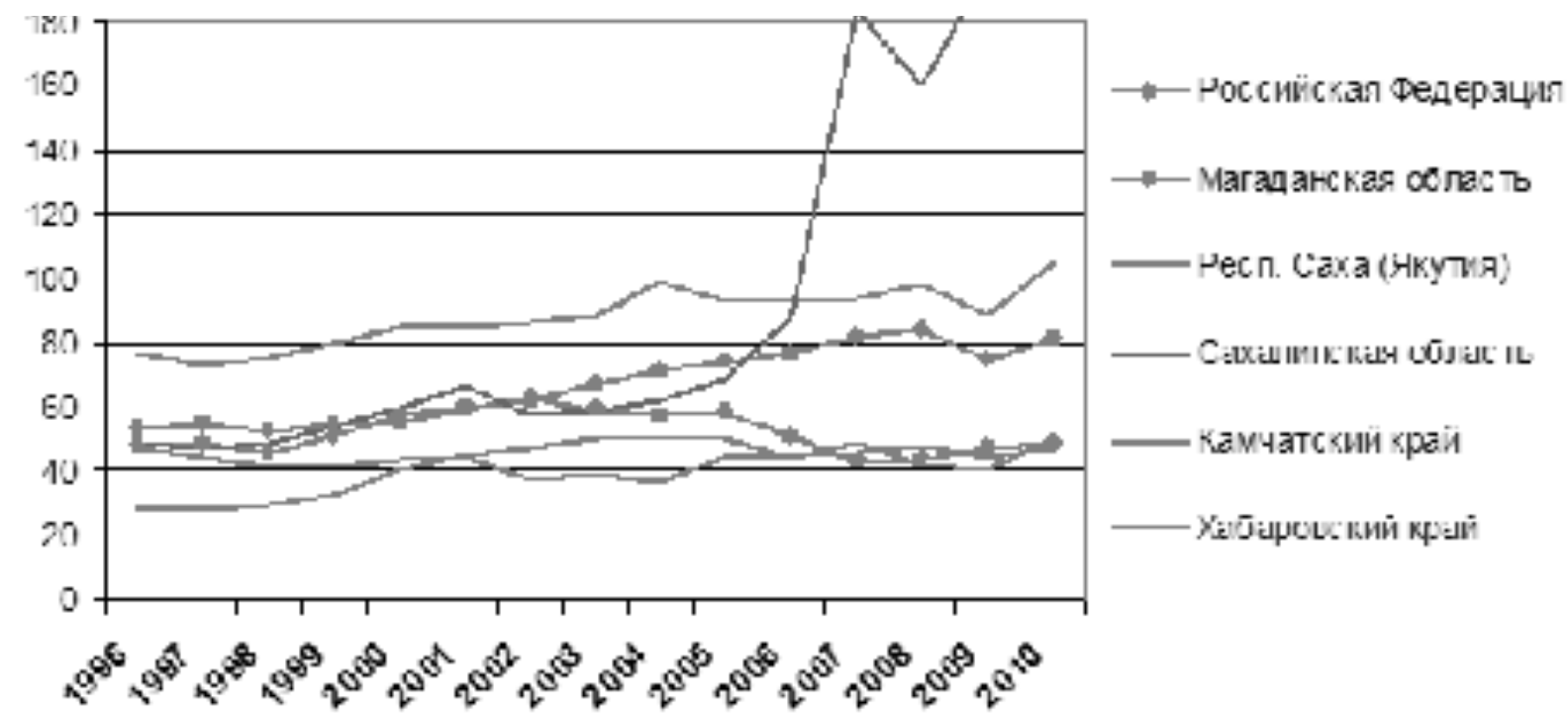

Russian Federation

Magadan region

Republic of Sakha (Yakutiya)

Sakhalin region

Kamchatka territory

Khabarovsk territory

Fig. 1. Dynamics of industrial production in the regions of the Far East, \% by 1990.

The region experienced a strong migration outflow: in the 1990s, the region lost more than half of the population (Table 1 and Figure 2). Especially this trend affected the rural areas and numerous

2Independent Institute of Social Policy [Electronic resource]. URL: http://www.socpol.ru/ atlas/portraits/magadan.shtml (accessed date 29.06.2017) 
industrial townships. The number of settlements significantly decreased: in 1989 there were 34 urban-type settlements in the region, and in 2002 - only 28, and 37 of 89 rural settlements had no population.

\section{Table 1.Estimation of the number of permanent population subject to municipal-territorial transformations (human) ${ }^{3}$}

\begin{tabular}{|c|c|c|c|c|c|c|}
\hline & \multicolumn{3}{|c|}{ as per January 1, 2017} & \multicolumn{3}{|c|}{ Average for 2016} \\
\hline & $\begin{array}{c}\text { all } \\
\text { population }\end{array}$ & $\begin{array}{c}\text { urban } \\
\text { population }\end{array}$ & 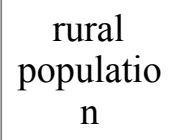 & $\begin{array}{c}\text { all } \\
\text { population }\end{array}$ & $\begin{array}{c}\text { urban } \\
\text { population }\end{array}$ & $\begin{array}{c}\text { rural } \\
\text { population }\end{array}$ \\
\hline $\begin{array}{l}\text { Magadan } \\
\text { region - total } \\
\text { including } \\
\text { urban } \\
\text { districts }\end{array}$ & $\begin{array}{r}145,54 \\
6\end{array}$ & $\begin{array}{r}139,29 \\
8\end{array}$ & 6,248 & 145,945 & 139,541 & 6,404 \\
\hline Magadan & 99,681 & 99,681 & - & 99,305 & 99,305 & - \\
\hline Magadan & 92,777 & 92,777 & - & 92,429 & 92,429 & - \\
\hline Olsky & 9,950 & 6,233 & 3,717 & 9,976 & 6,219 & 3,757 \\
\hline $\begin{array}{l}\text { Omsukchans } \\
\text { ky }\end{array}$ & 5,087 & 5,087 & - & 5,129 & 5,129 & - \\
\hline $\begin{array}{l}\text { Severo- } \\
\text { Evensky }\end{array}$ & 2,071 & 1,461 & 610 & 2,133 & 1,514 & 619 \\
\hline $\begin{array}{l}\text { Srednekansk } \\
\text { y }\end{array}$ & 2,375 & 2,226 & 149 & 2,449 & 2,282 & 167 \\
\hline Susumansky & 7,616 & 7,368 & 248 & 7,681 & 7,418 & 263 \\
\hline Tenkinsky & 4,283 & 3,286 & 997 & 4,406 & 3,359 & 1,047 \\
\hline Khasynsky & 6,648 & 6,208 & 440 & 6,865 & 6,407 & 458 \\
\hline Yagodninsky & 7,835 & 7,748 & 87 & 8,001 & 7,908 & 93 \\
\hline
\end{tabular}

\footnotetext{
${ }^{3}$ The territorial body of the Federal State Statistics Service for Magadan Region [Electronic resource]. URL: http://magadanstat.gks.ru/wps/wcm/connect/rosstat_ts/magadanstat/ru/statistics/population/ (accessed date 29.06.2017)
} 


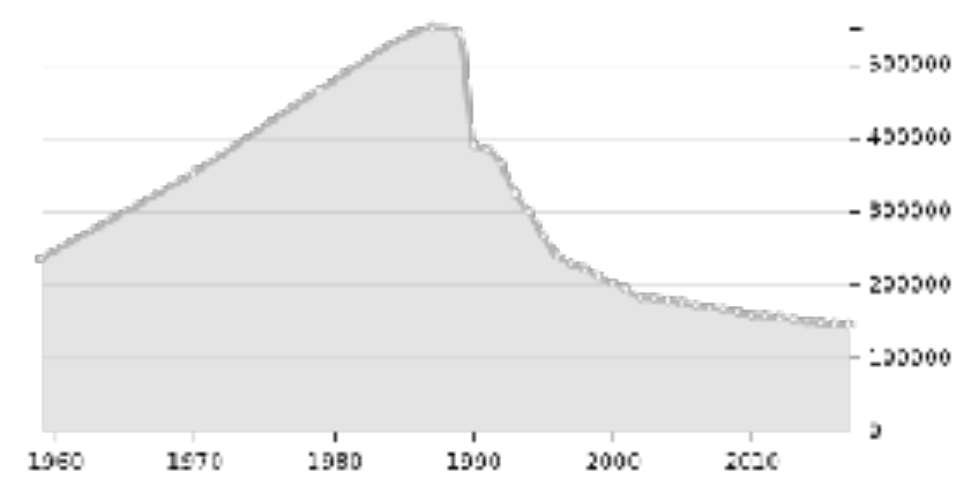

Figure 2. Dynamics of the population in 1959-2017 according to official results of population censuses including the former part of Magadan region - Chukotka Autonomous region 4

From the data presented, it can be concluded that the population continues decreasing to this day. Of course, this fact affects the inhabitants of this region and manifests itself in the "deferred life" syndrome, which affects the management and motivation of personnel.

The deferred life syndrome is a phenomenon when people do not live in the present, but prepare for life in the future (author's interpretation).

It is difficult to lead and motivate an employee who constantly thinks about moving to another region that is not interested in building long-term relations with the organization and can allow himself a disloyal attitude to its employer and to his own direct duties.

\section{DATA AND METHODS}

In Magadan, the author conducted an audit of personnel using a personal interview; projective methods [1,2,3,4,5], such as: metaphorical maps, "human figure drawing" Mahover K. test [6], Delleringer's psycho-geometric test [7], association with color, and also the definition of value orientations according to Rokich M. [8]. Within 3 years, 242 people were interviewed.

As a result, $72 \%$ of employees did not show a special interest in the development of the company. When answering the question about motivation, 90\% noted the interest only in the financial stimulation of work and $83 \%$ said they were raising their qualifications (with a focus on the "better tomorrow"). For example, in Moscow, about $67 \%$ of employees would prefer career growth even without wage increase, $78 \%$ of Moscow residents noted stability as one of the most favorable factors.

The management matters also experience influence of a severe, cold climate. About $67 \%$ of employees complained about health problems. Most of them have chronic diseases.

Remarkably, almost $70 \%$ of employees are ready to help another person to the detriment of their own interests. This altruistic deformation of personality is noted by many authors describing Magadan.

This phenomenon is explained simply: nothing better unites a group of people as a common enemy/difficulty. Against the backdrop of this enemy/difficulties, people forget about their problems and, helping each other, try to overcome it. In Magadan, such a "foe" was the climate, which is the link for people.

4 The territorial body of the Federal State Statistics Service for Magadan Region [Electronic resource]. URL: http://magadanstat.gks.ru/wps/wcm/connect/rosstat_ts/magadanstat/ru/statistics/ population/ (accessed date 29.06.2017) 
The altruistic personality deformation (APD) is an unselfish service to other people without regard for one's own interests, manifested under the influence of the harsh climate and remoteness of the region, due to the impossibility of independent hermitic activity (author's interpretation).

One can find the following information in the article of local residents: "From the point of view of morality, many cities can envy Magadan residents! People live here being always ready to help a stranger. Its the Northern Brotherhood in a word!". 5

APD complicates the business process by providing free of charge additional services, long-term deferred payment, etc. This aspect also influences motivation, making competition difficult to use among workers. However, APD allows sharing information in a team, simplifies team building.

Local residents note that the APD begins to show up in the individual after a year of living in Magadan.

It should be noted that Magadan is a small city with a population of about 100,000 people; the majority of residents have a pronounced external reference typical of such settlements. According to local residents "The city sleeps under one blanket", i.e. everyone knows everything about everyone.

External reference is dependence on someone else's opinion when making a decision [8].

As a result, one can speak about difficulties in upholding one's own opinion, about shifting responsibility, about manipulation, and difficulties in innovations. A compromise is a useful side of external reference, but not always a positive one, especially when it comes to the management of an organization.

This aspect (external reference) and the syndrome of deferred life, as a consequence, gives rise to the conflict of obligation.

The conflict of obligation is the difference between what a person actually wants and what he thinks he should do (author's interpretation).

Everywhere Magadan residents do/work/live where they don't want, but where, as they think, they should. For this reason, one can observe a general depressive mood, lack of wish and desire for something new. Much is hushed up and thus the process of management and motivation becomes more complicated.

Also we cannot ignore the fact that the fundamental moment in Magadan, in all aspects, both in management and in sales, is the personal relationships, which crucially hampers business processes. The author assumes that this is also a consequence of external reference, a small number of residents and remoteness and isolation from other regions.

\section{RESULTS}

The remoteness and peculiarity of this region imposes certain restrictions on the use of standard methods of management and motivation of personnel.

Management methods are ways to implement managerial influences on employees to achieve the objectives of organization management. There are economic, socio-psychological and administrative-legal methods of management distinguished, which differ in the ways and effectiveness of their impact on personnel [9].

${ }^{5} \mathrm{Ne}$ siditsia [Electronic resource].URL: http://nesiditsa.ru/city/magadan (accessed date 30.06.2017) 
Let's consider each method separately with respect to Magadan region. The main purpose of considering and using these methods is to minimize the impact of the deferred life syndrome and altruistic personality deformation, as well as a pronounced external reference, which, in the author's opinion, complicate the work process.

Economic management method

Economic management methods involve the use of material incentives for staff, such as: bonuses; allowances, lending, benefits; penalties and deductions, etc. [10].

Methods of economic management are determined by: the form of ownership, the size of the organization, the labor market, market pricing, etc. [11,12,13].

Next, we consider the main tools of economic management in relation to Magadan region, taking into account the dynamics (reduction) of the labor market and pricing features. However, this paper will not take into account the form of ownership, the size of the organization, etc. The prices in this region are higher than in other regions of the Russian Federation (see Table 2 / Information on the prevailing prices for basic food products in comparison with prices in the Far Eastern Federal District as of October 2016).

Table 2. Comparison of prices for basic food products 6

\begin{tabular}{|c|c|c|c|c|c|c|c|c|}
\hline Product name & $\begin{array}{l}\text { Yak } \\
\text { uts } \\
\mathrm{k}\end{array}$ & $\begin{array}{l}\text { Petr } \\
\text { opa } \\
\text { vlo } \\
\text { vsk } \\
- \\
\mathrm{Ka} \\
\mathrm{mc} \\
\text { hats } \\
\text { ky }\end{array}$ & $\begin{array}{l}\text { Vla } \\
\text { div } \\
\text { ost } \\
\text { ok }\end{array}$ & $\begin{array}{l}\mathrm{Kh} \\
\mathrm{aba} \\
\text { rov } \\
\text { sk }\end{array}$ & $\begin{array}{l}\text { Bl } \\
\text { ag } \\
\text { ov } \\
\text { es } \\
\text { hc } \\
\text { he } \\
\text { ns } \\
\text { k }\end{array}$ & $\begin{array}{l}\text { Ma } \\
\text { gad } \\
\text { an }\end{array}$ & $\begin{array}{l}\text { Yuz } \\
\text { hno } \\
- \\
\text { Sak } \\
\text { hali } \\
\text { nsk }\end{array}$ & $\begin{array}{l}\text { An } \\
\text { ady } \\
\text { r }\end{array}$ \\
\hline $\begin{array}{l}\text { Whole pasteurized drinking milk } 2.5-3.2 \% \text {, } \\
1\end{array}$ & 80 & 97 & 74 & 73 & 57 & 90 & 78 & 104 \\
\hline Chicken eggs, 10 un. & 78 & 98 & 65 & 68 & 61 & 85 & 84 & 109 \\
\hline Dry milk formulas for babies, $\mathrm{kg}$ & $\begin{array}{l}1,11 \\
4\end{array}$ & 950 & $\begin{array}{l}1,02 \\
1\end{array}$ & $\begin{array}{l}1,03 \\
3\end{array}$ & $\begin{array}{l}96 \\
6\end{array}$ & $\begin{array}{l}1,57 \\
2\end{array}$ & $\begin{array}{l}1,02 \\
4\end{array}$ & $\begin{array}{l}1,65 \\
2\end{array}$ \\
\hline Bone-in beef, $\mathrm{kg}$ & 425 & 534 & 403 & 384 & $\begin{array}{l}35 \\
2\end{array}$ & 404 & 431 & 589 \\
\hline Bone-in pork & 345 & 435 & 361 & 306 & $\begin{array}{l}34 \\
2\end{array}$ & 303 & 358 & 505 \\
\hline $\begin{array}{l}\text { Bread from rye flour and from a mixture of } \\
\text { rye and wheat flour, } \mathrm{kg}\end{array}$ & 73 & 70 & 83 & 78 & 43 & 91 & 65 & 104 \\
\hline Sour cream, kg & 291 & 465 & 203 & 189 & $\begin{array}{l}17 \\
0\end{array}$ & 443 & 331 & 518 \\
\hline Fatty cottage cheese, $\mathrm{kg}$ & 415 & 439 & 361 & 316 & $\begin{array}{l}31 \\
1\end{array}$ & 455 & 369 & 489 \\
\hline
\end{tabular}

6Безформата.ru Information on prices for basic food products [Electronic resource]. URL: http://magadan.bezformata.ru/listnews/tcenah-na-osnovnie-prodovolstvennie-tovari/ 51613774/ (accessed date 14.08.2017)

Submit Date: 09.01.2018, Acceptance Date: 23.02.2018, DOI NO: 10.7456/1080MSE/144

Research Article - This article was checked by Turnitin

Copyright (C) The Turkish Online Journal of Design, Art and Communication 
- Salary - remuneration for work, accrued depending on the complexity of the work performed, the qualification of the employee, the number of tasks to be performed, etc.

\section{Main rules:}

1. Delays in payment of wages are not permissible (part 6, Article 136 of the Labor Code of the Russian Federation 7 ;

2. Salary should not stay on the same level for a long time.

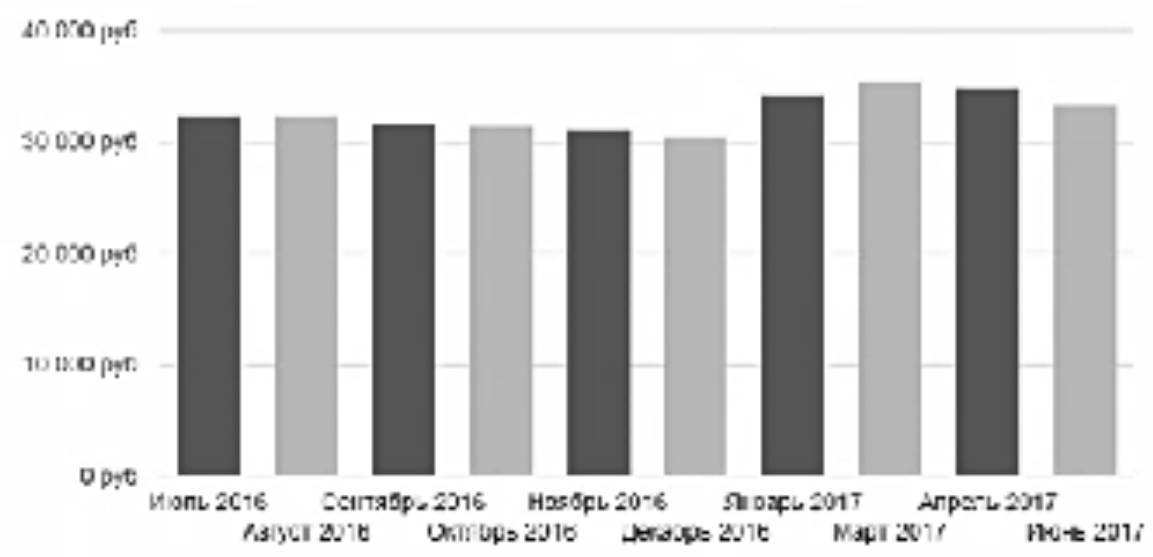

June $2016 \quad$ September $2016 \quad$ November $2016 \quad$ January 2017 April 2017

August 2016 October $2016 \quad$ December $2016 \quad$ March $2017 \quad$ July 2017

Figure 3. Average salary in Magadan ${ }^{8}$

In the author's opinion, considering the peculiarities of Magadan region, namely the deferred life syndrome, it does not make sense to offer employees a high salary. For effective motivation of employees, it makes sense to limit oneself to the average indicators (see Figure 3) and use additional instruments of monetary stimulation.

- Bonus is an incentive payment paid in excess of wages received by employees for more thorough performance of work duties or achievement of certain indicators.

Competent application of the bonus system can reduce costs and save on the payroll fund, as well as increase motivation [14] and employee efficiency [15].

It is advisable to develop a provision on bonuses, which will describe the main indicators and conditions, as well as the size of the payment of bonuses. This document will prevent9:

7the Labor Code of the Russian Federation. Revised as of June 01, 2017. Publishing house: Eksmo, 2017. - 224

8 TRUD. com/ Review of labor market statistics in Magadan [Electronic resource]. URL: http:// magadan.trud.com/salary/1953.html (accessed date 04.07.2017)

${ }^{9}$ Calculation of the northern allowance in the regions of the Far North - 2016 - 2016 [Electronic resource]. URL: www.nsovetnik.ru (accessed date 30.07.2017) 
$\checkmark \quad$ claims of tax authorities on the inclusion of bonuses in the composition of labor payment costs when calculating income tax;

$\checkmark \quad$ disputes with the Social Insurance Fund on the calculation of temporary disability benefits.

Employees often treat bonuses as an integral part of wages [16] and its absence is perceived as punishment. It is advisable, including in the region under consideration, to use one-time bonus options, avoiding permanent payments, which will have a good effect on external reference. Monthly paid bonuses lead to the loss of the proper motivational effect. In this case (with constant bonuses) it is reasonable to use small amounts (a small percentage in relation to wages, not more than $50 \%$ ).

- Allowances - additional remuneration for particularly difficult working conditions, as well as for more qualified execution of work.

Magadan refers to the list of cities and districts, which presuppose the so-called "northern benefits": preferential term of service in the award of pensions; additional vacation; wage allowance - "northern coefficient", etc. ${ }^{10}$

\section{Main rules:}

1. The district coefficient does not apply to the accrual of bonuses, long-service bonus and financial assistance (the district coefficient in Magadan is 1.7 , and there is also a northern premium of $1.8[17])$

2. Continuity of service is not taken into account

3. Private and public organizations equally charge additional payments.

4. Every six months in Magadan, salary increases by $10 \%$. The maximum amount of additional payment is $80 \%$ of the base salary.

In addition to the payments provided by law, the author proposes to introduce additional allowances pegged against the employee's rating. This will help to increase the individual interest of workers [18] and minimize the consequences from the altruistic deformation of the individual.

- Lending - provision of financial support to employees on preferential terms.

Financial problems have a very bad effect on the staff performance, and their solution at the expense of the organization increases loyalty. At the same time the company concludes a contract with the employee about a certain period of work, during which the employee shall not resign, and, in case of its violation, pays a penalty and returns the remaining amount of debt immediately. Subject to the terms of the contract, the enterprise deducts a small portion of the monthly salary.

Author's recommendation: the loan is granted for non-deferred needs, for a period of not more than 2 years, and for amounts commensurate with salary.

If we talk about Magadan, then this tool is in good agreement with APD, and also reduces the impact of the deferred life syndrome.

- Benefits - additional goods provided by the enterprise to its employees, increasing their standard of living [19].

10 Calculation of the northern allowance in the regions of the Far North - $2016-2016$ [Electronic resource]. URL: www.nsovetnik.ru (accessed date 30.07.2017) 
In order to increase loyalty, the company's employees can be offered voluntary health insurance (VHI), phone payment, the possibility to use the corporate car, free meals, training, life insurance, etc.

The study of Magadan, as it was written earlier, revealed problems with health in the majority of subjects, therefore, it is most expedient to use VHI.

Also, given the remoteness of the region, it is possible to offer a preferential air flight (partial payment of the air ticket at the expense of the company to the mainland) [20]. This helps to partially level the deferred life syndrome. The individual has the opportunity to rest more often, and suffer less from "professional burnout".

- Penalties - the monetary penalty imposed on an employee in case of violation of the internal code of conduct/labor contract [21].

Disciplinary sanctions that can be applied to employees are specified in Part 1 of Article 192.

These include:

1. Dismissal

2. Rebuke;

3. Reprimand.

A fine as deduction of a part of salary is not permissible!

The employer may not pay a portion of the premium, or another motivating payment [22].

The author does not recommend to use this tool in Magadan. This is poorly consistent with the external reference and with APD. It is possible to reduce the bonus, but for this, everything must be recorded to the maximum and the decision must be made on the basis of the internal code of conduct (if the manager makes this decision (not specified in the company's internal document), in the studied region, the individual faces a serious internal / psychological conflict).

As a punishment, ignoring can be used (discussed below).

\section{$\underline{\text { Socio-psychological methods of management }}$}

These include social and psychological methods and methods of influencing the process of development and formation of the work team, such as: moral encouragement, social planning, persuasion, suggestion, personal example, ignoring, etc. [23]

For Magadan this is the most effective method, which agrees well with the identified problems.

- Moral encouragement of the employee - satisfaction of the social or spiritual needs of the individual. It is manifested in the recognition of merit before the organization, respect, etc. [24]

Forms of moral encouragement:

1. Conferral of the title The Best Employee;

2. Commendation;

3. Awarding of certificate of honor;

4. Presentation of a commemorative award;

5. Honor board. 
The studied region is in good agreement with the external reference (demonstration of the positive side of the individual to others, increase in the importance), but there may be a slight internal conflict with APD (the sense of guilt that the employee is better than colleagues), the effect on the deferred life syndrome (negative: I could do it here, so can do in another place; positive: there is a need to work some more time (distance recognition in time) to become the best, i.e. the employee sees an achievable goal).

In Magadan, this tool is mainly used in state-owned companies, which significantly restricts commercial organizations.

It is necessary to regulate in the internal document of the organization the conditions the employee can be awarded such an honorary title for. This tool increases the interest and loyalty of employees.

- Social planning - development and practical implementation of plans, determining the future state of the social sphere and ways to achieve it.

The social development plan of the organization contains:

1. Improvement of staff incomes;

2. Improvement of quality of life;

3. Improvement of labor potential;

4. Development of creative abilities of personnel, etc.

It is rarely used in the Russian commercial organizations, however for Magadan region it seems most relevant.

The main task of the employer is to inform employees about the social development plan, make it as accessible as possible, and fix the main achievements in this direction.

This tool has a good effect on the "deferred life syndrome". The individual falls into the power of social psychology, becomes part of the organization, changes his way of thinking.

- Persuasion is a trust in the worldview of the leader, towards the development of the company as a whole, based on a complex of confirmatory elements (author's interpretation).

To use this tool, it is necessary to formulate the company's global goal, mission.

A modern employee often wonders about the meaning of his work, about the benefits he brings. Persuasion is used to reduce this aspect and the effect of APD by guiding it in the right direction.

- Suggestion is an action aimed at changing the behavioral characteristics of a person, his mental and emotional state [24]. It is a manipulation to improve the workflow.

Suggestion is carried out by verbal and non-verbal methods, through the imposition of a certain emotional state, mood, etc.

Suggestion differs from persuasion in that it is not based on logical arguments.

In a region with such climatic features and remoteness as Magadan, the emotional comfort of the employee is of great importance. For this purpose, such things like aromadesign, warm color and light, as well as musical accompaniment of the workflow should be used [25].

For example, audio-marketing increases the overall efficiency of employees by $15 \%$, activity in the first hour of work increases by $10 \%$, the number of errors decreases by $30 \%$.

It is an excellent tool that influences the conflict of oughtness. 
- Ignoring - the impact on human behavior, with a view to changing it, through inattention, neglect (author's interpretation).

It makes sense to encourage acceptable behavior and ignore unacceptable11.

Since the system of penalties is very limited, and is difficult to apply in Magadan, where external reference and APD are strongly manifested; it is more appropriate to use an ignoring tool as a punishment. One should not focus on negative aspects, but maximally encourage positive ones. It makes sense to talk with a staff member eye-to-eye and say what exactly is not right, but do not focus on these points with the team. If the individual does not understand, then ignore the misses in the work until the latter realizes it.

Author's recommendation: use the ignoring tool effectively within one month (not more). If during this period the result is not achieved, it makes sense to change the nature of the response.

\section{Administrative and legal methods of management}

These methods of direct impact, based on directive management, include: organizational and administrative option, disciplinary, material and administrative responsibility, as well as fines [23].

- Organizational impact - presupposes the existence of approved internal regulatory documents governing the activities of employees (company charter, organizational structure, staff schedule, regulations, collective agreement, job descriptions, internal code of conduct).

This tool is an obligatory form of management, excluding subjective perception by management of the situation and solving many problems. Individual responsibility for certain decisions is eliminated, which is good for external reference. The more things are regulated, the less controversial the situation is. It is especially important for Magadan.

- Regulatory influence - focuses the attention of the work team on achieving the set objectives of the enterprise, compliance with the requirements of internal regulatory documents and the maintenance of certain parameters of the management system through direct administrative regulation (orders, labor standards, instructions, orders, etc.).

To implement this method, it is necessary to set and explain the mission of the company, the overall vision, the strategy. The more meaningful the work is, the more effective the efforts become. It is an excellent option for reducing the syndrome of deferred life, and external reference.

- Disciplinary responsibility is the prescribed code of conduct consistent with the norms of the Labor Code, laws, contracts, internal company rules, mandatory for all employees, provided that the necessary conditions are created by the employer.

Tt is difficult to implement in Magadan because of external reference and APD. However, the author insists on the need to use this toolkit. Without the use of any punishment, the loyalty and responsibility of employees is reduced. It is necessary to remember that the syndrome of deferred life directly affects self-motivation and self-control by reducing them. For the team to work more harmoniously, there must be inevitability of punishment. That will keep employees within certain limits.

- Penalties - a punishment imposed on the company's employee, if the latter violates his job duties. They must be documented.

Penalties include: reprimand, rebuke and dismissal. The employer cannot apply other variants of fines (discussed above).

It is rarely used in Magadan due to a very limited labor market. Another factors complicating the process of applying punishments are APD and external reference.

\footnotetext{
${ }^{11}$ Womanadvice.ru Psychology of Ignoring [Electronic resource]. URL: http://womanadvice.ru/ psihologiya-ignorirovaniya (accessed date 20.09.2017)
} 
There is another option for using this tool - the "last chance". When the manager indicates that due to his early merits to the organization he is ready to soften the punishment, but this is the last time. Thus, the recovery is postponed until the unsatisfactory situation repeats.

At the same time, an awareness of the possibility of recovery by an employee will influence his external reference. After such a precedent, the probability of finding a decent job in the Magadan region is significantly reduced.

\section{SUMMARY}

As a conclusion, the author notes that the peculiarity of the studied region does not allow for the use of standard measures for managing and motivating staff. It is necessary to take into account the characteristics of employees when planning motivational activities (see Table 3).

Table 3.The influence of management tools on the main features of Magadan employees (author's interpretation)

\begin{tabular}{|c|c|c|c|}
\hline tool & $\begin{array}{l}\text { Deferred life } \\
\text { syndrome }\end{array}$ & $\begin{array}{l}\text { Altruistic personality } \\
\text { deformation }\end{array}$ & $\begin{array}{l}\text { Ex t e r n a l } \\
\text { reference }\end{array}$ \\
\hline \multicolumn{4}{|c|}{ Economic management methods } \\
\hline Salary & + & & \\
\hline Bonus & & & + \\
\hline Allowances & + & & + \\
\hline Lending & + & + & \\
\hline Benefits & + & + & \\
\hline Penalties & & & + \\
\hline \multicolumn{4}{|c|}{ Socio-psychological methods of management } \\
\hline $\begin{array}{l}\text { M o } \quad r \quad \text { a } 1 \\
\text { encouragement } \\
\text { of an employee }\end{array}$ & + & & + \\
\hline Social planning & + & & \\
\hline Persuasion & & + & \\
\hline Suggestion & + & & \\
\hline Ignoring & & + & + \\
\hline \multicolumn{4}{|c|}{ Administrative and legal methods of management } \\
\hline $\begin{array}{l}\text { Organizational } \\
\text { influence }\end{array}$ & & + & + \\
\hline $\begin{array}{l}\text { R e g u l a t ory } \\
\text { influence }\end{array}$ & + & & \\
\hline $\begin{array}{l}\text { Disciplinary } \\
\text { responsibility }\end{array}$ & & + & + \\
\hline
\end{tabular}




\begin{tabular}{|l|l|l|l|}
\hline Penalties & & + \\
\hline
\end{tabular}

The author also proposes to introduce rating of employees as an additional motivational tool, which in the future will be the basis for the introduction of KPI.

The rating of employees is the division of employees depending on their qualification and work performed within one department, with clearly defined values for increasing and lowering the rating, as well as changes in labor remuneration (author's interpretation).

The introduction of this tool will minimize the manifested features (see Table 4).

Table 4.The effect of leveling regional features of staff motivation through the introduction of staff rating (author's interpretation)

\begin{tabular}{|l|l|}
\hline $\begin{array}{l}\text { Regional features of } \\
\text { the employees }\end{array}$ & $\begin{array}{l}\text { Description of the effect of leveling through the } \\
\text { introduction of staff ratings }\end{array}$ \\
\hline Deferred life syndrome & $\begin{array}{l}\text { Rating discovers in employees similar goals that } \\
\text { allow an individual to concentrate on achieving } \\
\text { them and plan his life depending on understandable } \\
\text { criteria. This does not exclude the desire to move } \\
\text { out of this region, but switches a person to the "here } \\
\text { and now" state, so that it becomes more manageable } \\
\text { and predictable. }\end{array}$ \\
\hline $\begin{array}{l}\text { Altruistic personality } \\
\text { deformation }\end{array}$ & $\begin{array}{l}\text { The introduction of this tool gives rise to a desire to } \\
\text { achieve more, including through help to colleagues, } \\
\text { i.e. this feature is used for good purposes. } \\
\text { There is also the described objective reduction } \\
\text { factor independent from the subjective opinion of } \\
\text { the leader, which excludes the psychological } \\
\text { conflict of the latter. }\end{array}$ \\
\hline External reference & $\begin{array}{l}\text { Rating allows quickly reveal leaders. Positive } \\
\text { qualities of the employee are demonstrated both for } \\
\text { the team and for clients / customers, which agrees } \\
\text { perfectly with the feature in question. }\end{array}$ \\
\hline
\end{tabular}

The study of the material showed that staff management and motivation should take into account the national, religious, psychological, climatic and geographical features of the region. The peculiarities of Russia are such that there is a need for research and development of motivational tools for each region separately. And only in this case it is possible to count on a positive result in personnel management.

\section{Conflict of interests}

The author declares that the provided information has no conflicts of interest.

\section{Acknowledgements}

The author thanks the company Omnikomm Magadan represented by General Director Morozov Aleksandr Valentinovich for the opportunity to conduct study.

Also many thanks to Galina Karachanskaia and Ekaterina Simonova for the provided information, comments and support.

\section{REFERENCES}

Burlachuk, L. F. (2006) Psychodiagnostics: A Diagnostics. - SPb.: Peter-351 p. 
Shapar, V. B., Shapar, O. V. (2006) Practical psychology. Proektnye techniques - Rostov n/D: Feniks. -480 p.

Tsuladze, S. V. (1989) About the place and value of projective methods in the study of personality // Problems of personality. $-M$. $-256 \mathrm{p}$.

Shapar, V. B. (2005) Workbook is a practical psychologist. - Moscow: ACT.- 336 p.

Grebeniuk, A. A. (2003) Projective techniques of personality-Simferopol. - 264 p.

Alexeev, A. A., Gromova, L. A. (1991) Psychogeometry for managers. - In: Knowledge. $-176 p$.

Gilbreth, L. M. (2012) The Psychology of Management: The Function of the Mind in Determining. $365 p$.

Koniukhov, N.I., Arkhipova, O. N., Koniukhova, E. N. (2011) Psychoeconomic From: M. Delhi plus. -228 p.

Lochan, S. A. Fediunin, D. V. Bezpalov, V. V., Petrosian, D. S. (2015) Theoretical issues of the formation of the industrial policy of enterprises. International Journal of Economics and Financial Issues. Vol. 5. No. 3S. P. 274-280.

Fedoseev, V. N., Kapustin, S. N. (2004) Methods of personnel management study guide. M.: Exam. $-292 p$.

Managing Markets and Customers. Pergamon, 2009 - 132 p.

Cotton, D. (2008) Keys to Management. Longman, 224 p.

Kudriavtseva, S. S. Shinkevich, A. I., Ostanina, S. S., Vodolazhskaia, L. E., Khairullina, R. E., Chikisheva, N. M., Lushchik, I. V., Shirokova, L. V. (2016) The methods of assessing national innovation systems. International Review of Management and Marketing. Vol. 6. No. 2. P. 225-230. Gumerov, A. V., Kharisova R. R., Nabiullina K. R., Pavlova, A. V. Litvin, I. Y., Schepkina N. K., Sabirov, I. T. (2015) Improving strategic management of the business entities. Review of European Studies. Vol. 7. No. 1. P. 23-28.

Weber, W. (1990) Personal-Controlling // Zeitschrift fuer Personalforschung, №1, S.61-65.

Konovalenko, V. A., Konovalenko, M. Iu., Solomatin, A. A. (2017) Psychology of management. Theory and practice. Tutorial for bachelors. - M. : Urait. $-368 p$

Nosova, S.S., Sorokina, G.P., Liubimtseva, S.V., Afanasyev, A.A., Zvezdichev, G.Iu. (2017) Conceptual approaches to overcoming turbulence in the innovative development of Russian industrial enterprises. International Journal of Applied Business and Economic Research. V. 15. No. 13. pp. 223-230.

Nosova, S.S., Abdulov, R.E., Medvedeva, Y.M. (2016) Analysis of the factors affecting the development of economic culture of a family in the RF based on experience of developed countries. International Review of Management and Marketing. V. 6. No. 3. pp. 222-228.

Nikiforov, G. S. (2000) The psychology of management: Textbook ledited by Professor-SPb.: Publishing house -St. Petersburg University - 572 .

Gorbunov,M. Y. (2008) Personnel management and psychology of management: the concise course of lectures - Moscow: VLADOS-PRESS. - 223 p.

Kennedy, D. (2012) Tough management: Make people work for the result / Dan Kennedy; TRANS. from English. - M.: Al'pina Pablisher. - 292 p.

Adizes, I. K. (2014) The Ideal Executive: Why I can't be and thus. - Alpina Publisher; Moscow$264 \mathrm{p}$.

Gumerov, A. V., Fatikhova, E. L., Iusupova, G. F., Kolpakov, K. O., Nabiullina K. R., Litvin, Y. I., Suchkova, S. Y. (2015) Features of forming an interaction network of an entrepreneurial structure. Review of European Studies. Vol. 7. No. 4. P. 209-215.

Cialdini, R. B. (2001) The Psychology of influence. - SPb.: Peter- 288 p.

Shkliar, T. L., Vasilyev, S. V. (2016) Modern working conditions in a competitive society the online magazine "science of Science" Volume 8, Number 5 (36) (May-June), 2016Shkliar T. L., Vasilyev S. $V$. Modern working conditions in a competitive society the online magazine "science of Science" Volume 8, Number 5 (36) (May-June) 